\title{
EDUCATION FOR SUSTAINABLE DEVELOPMENT AT HIGHER EDUCATION INSTITUTIONS: A CRITIQUE
}

\author{
Paul Pace \\ University of Malta, Malta
}

Since the inception of the concept of education for sustainable development (ESD) (UNCED, 1992, Chapter 36, par.3), higher education institutions (HEls) have been considered key actors in its promotion. HEls were expected to achieve this by leading students to contextualise their learning within the realities of their own specialisation, profession and personal life by encouraging them to develop: (a) the notion of global citizenship; (b) a commitment towards environmental stewardship; (c) a reflection about the interaction between issues of social justice, ethics, wellbeing and ecological and economic factors; and (d) a commitment towards actively ensuring sustainable futures (Longhurst, 2014, p.5).

However, Orr's reflection while watching the yearly procession of graduands that "... without significant precautions, education can equip people merely to be more effective vandals of the earth" (Orr, 1994, p.5) is quite telling. Considering the resources invested in HEls and the time elapsed since ESD's learning objectives were spelled out, one would expect much greater achievements in the realm of sustainable development. This does not mean that there are no great examples where HEls have done a great job at promoting sustainability (UNESCO, 2014a), but one must admit that, when looking at the whole picture, these are relatively isolated cases and that the overall picture is rather bleak.

The root of the problem might lie in the way HEls are traditionally programmed to respond to the needs; i.e. quickly defining the issue (with the mental framework available), identifying the available expertise required and structuring a learning programme (with the resources available). However, this does not come anywhere near the radical rethinking and innovation that ESD provision entailed (Pace, 2010a). Being only a short-term response to the educational and administrative challenges that ESD demands, this greenwashing of HEls failed to deliver the autonomous critical lifelong learners they were expected to develop.

Effective ESD necessitates a whole-institution approach that implies: (a) a shared vision and implementation plan involving all stakeholders - administration, leadership, teachers and learners; (b) channelling resources to support this reorientation; and (c) consolidating networks to promote collaboration (UNESCO, 2014b, p.35). A whole-institution approach thus implies a deeper change in the various levels of decision-making, traditional curricular structures and the complex nature of educational system. But such deep changes generate uncertainties and come at a cost (certainly not just financial) ... a cost that not all HEls are ready to shoulder. When dealing with ESD, HEls should humbly and honestly reflect and possibly rethink what they teach, why they teach it and how they teach it.

The Delors report identifies seven tensions that are central to the problems of the twenty first century and should be central to any ESD programme:

- The tension between the global and the local;

- The tension between the universal and the individual;

- The tension between tradition and modernity;

- The tension between the long term and short term considerations;

- The tension between the need for competition and the ideal of equality of opportunity;

- The tension between the expansion of knowledge and our capacity to assimilate it; and

- The tension between the spiritual and the material (Delors et al., 1996, pp.15-16).

Moreover, since HEls are also part of society, they need to realise that they have to contend with these dilem- 
mas not just as 'themes' in their curricula, but also as issues that shape the profile of the institution. Moore (2005, p.543) identifies the following four barriers that ESD programmes face at HEls:

1. Monodisciplinary organisational structures that determine funding, result in territorial conflicts and limit student mobility from one area to another.

There was a time when disciplines blossomed in response to our thirst to understand more the complexities of our surroundings. Over the years, disciplines have become ends in themselves, able to generate their own importance, irrespective of whether they provide relevant explanations to reality. HEls have institutionalised this disconnectivity by formalising and enforcing disciplinary boundaries, and chastising staff and students who engage in inter/transdisciplinary work as "Jack of all trades". Besides, being in direct conflict with the systems approach (characteristic of ESD) this narrow monodisciplinary perspective limits our ability to resolve multidimensional messy problems by proposing neatly packaged one-size-fits-all solutions." The dimensions of sustainable development, in which economic growth is guided by environmental stewardship and concern for social justice, require an integrated approach to education that addresses multiple social, ethical, economic, cultural, civic and spiritual dimensions" (UNESCO, 2015, p.38).

2. Competition between and within students, faculties, departments and universities.

Irrespective of the importance various ESD guidelines attribute to collaboration, sharing of expertise and networking; exclusivity, self-sufficiency and competition are still rampant in ESD circles ... and HEls League Tables are certainly not helping in this matter (Bawden, 2015). In an effort to further their ESD profile HEls excel in spawning 'intellectuals' who through their academic ramblings and the use of ensuing specialised discourse establish themselves as gurus in the field. This is what Smyth (1995) had warned about, i.e. the establishment of the "priesthood of the environmentally enlightened" that effectively bars individuals, organisations, policymakers and sectors from society that are not familiar with the new'religion' from active participation in the promotion of sustainability.

3. Misdirected criteria for evaluating staff and student abilities and achievements.

Stemming from the previous barriers is the definition of what is relevant - and hence has currency - in academic circles. A lot of academics are familiar with the adage "publish or perish" which per se highlights the importance of engaging in research. However, publishing in academic journals (and its related implications on sponsorship and career advancement) has become an end in itself and a flawed yardstick in evaluating staff (and students). It has reportedly shifted the emphasis from research quality to an irrational craze among academics to assemble lengthy publication lists. Consequently, we are witnessing a disturbing increase in papers that - although publishable - focus on narrow (at times insignificant) research questions with little (if any) relevance to the sustainability challenges we are facing. Moreover, access to particular (at times influential) journals is often determined by the level of conformity with particular agendas, practices and formats rather than by academic prowess. This undue emphasis on publications detracts staff from participating in activities (such as teaching/supervising students and community-based work) that although being significant and socially responsible are not valued in the traditional evaluation procedures of HEls.

4. Too many priorities, unclear decision-making and hierarchical power structures.

$\mathrm{HEl}$ tend to give a lot of lip service to ESD, but at the same time their practice is riddled with incongruences. It is as though while HEls have a lot to teach about ESD, they are still not convinced enough about ESD to live by what they preach. The inherent message given is that ESD is not relevant ... it is just an academic pursuit. Besides the incongruences with ESD principles already mentioned, HEls seem to have an innate fear of change, primarily because change threatens established power structures: at the micro level (i.e. involving relationships between staff and students), at the meso level (i.e. involving inter faculty/institutes/centres) and at the macro level (between HEls). If HEls could embrace change more openly, they could effectively prepare students to become change agents who anticipate, face and react to change - the only predictable feature of the unknown future they will have to face.

Priority Action Area 3 of the Global Action Programme on ESD emphasises building capacities of educators and trainers (UNESCO, 2014b) because they are the people at the forefront - the ones, who with their training in transformative pedagogies and assessment for learning will transform learners into inquisitive, reflective, experienced and critical thinking individuals, i.e. the basic unit of a sustainable society (Pace, 2010b). Although this Priority Action Area addresses the preparation of all educators and trainers (not just school teachers), HEls still select staff on the basis of their publication lists rather than on their level of pedagogical formation. 
In conclusion, as previously mentioned, there are nevertheless documented cases (e.g. Leal Filho \& Pace, 2016) where HEls have been quite successful in educating for sustainable development. The following is a summary of the most successful features adopted by these HEls (see also Moore, 2005):

- Less importance given to the jargon used and increased emphasis on finding ways of implementing the principles of ESD.

- A preference to develop programmes that are culturally sensitive to the contexts in which they are operating rather than adopting ready-made off-the-shelf solutions from other countries/regions.

- Promoting a continuum of curricular solutions that propose integrated themes that are cross disciplinary, that while retaining the traditional focus of individual disciplines, still provide the opportunity for multi/interdisciplinary examination of real-life situations.

- A marked emphasis on the development of competences and autonomous learning rather than just on the acquisition of knowledge.

- The adoption of conscious measures to increase student participation, not just during the learning sessions, but also in the design and assessment of the programme. This brought about a change in the mindsets of students, their tutors and the management staff of their respective universities.

- The adoption of out-of-classroom sessions that involve a greater engagement with nature as well as community spaces (including the HEl campuses themselves).

- Featuring and critically reflecting on success stories and role models/examples that offer an antidote to the feelings of insecurity and despair.

- The commitment of HEls towards ESD was directly proportional to the political/legislative motivation to promote ESD. Without this motivation the process is more laborious and vulnerable to changes.

\section{References}

Bawden, A. (2015, January 20). How green is my university? The Guardian. Retrieved from https://www.theguardian.com/ education/2015/jan/20/how-green-university-people-planet-green-league.

Delors, J. et al. (1996). Learning: The treasure within. Paris: UNESCO.

Leal Filho, W., \& Pace, P. (Eds.). (2016). Teaching education for sustainable development at university level. Switzerland: Springer International Publishing.

Longhurst, J. (2014). Education for sustainable development: Guidance for UK higher education providers. Gloucester, UK: The Quality Assurance Agency for Higher Education.

Moore, J. (2005). Barriers and pathways to creating sustainability education programs: Policy rhetoric and reality. Environmental Education and Research, 11 (5), 537-555.

Orr, D. W. (1994). Earth in mind: On education, environment, and the human prospect. Washington: Island Press.

Pace, P. (2010a). Education for sustainable development: Current fad or renewed commitment to action? Journal of Baltic Science Education, 9 (4), 315-323.

Pace, P. (2010b). Self-evaluation as a tool in developing environmental responsibility. Journal of Teacher Education for Sustainability, $12(1), 5-26$.

Smyth, J. C. (1995). Environment and education: A view of a changing scene. Environmental Education Research, 1 (1), 3-20.

UNCED (United Nations Conference on Environment and Development) (1992). The United Nations Conference on Environment and Development: A guide to Agenda 21. Switzerland: UN Publications Office, Geneva.

UNESCO (2014a). Shaping the future we want: UN decade of education for sustainable development (2005-2014) Final Report. Paris: UNESCO.

UNESCO (2014b). Roadmap for implementing the Global Action Programme on education for sustainable development. Paris: UNESCO.

UNESCO (2015). Rethinking education: Towards a global common good. Paris: UNESCO.

Received: June 20, 2016

Accepted: June 30, 2016

Paul Pace

PhD., Associate Professor and Director, Centre for Environmental Education \& Research, University of Malta, Room 327, Faculty of Education, Msida MSD 2080, Malta.

E-mail: paul.j.pace@um.edu.mt 